\title{
PHENOLIC AND FLAVONOID CONTENT AND ANTIOXIDANT EVALUATION OF HAWTHORN (Crataegus monogyna Jacq.) FRUITS AND LEAVES EXTRACTS
}

\author{
VIDOSLAV DEKIĆ ${ }^{*}$, NOVICA RISTIĆ ${ }^{1}$, BILJANA DEKIĆ ${ }^{1}$, MILENKO RISTIĆ ${ }^{1}$
}

${ }^{1}$ Faculty of Science and Mathematics, University of Priština, Kosovska Mitrovica, Serbia

\begin{abstract}
Considering the facts that phenolic compounds have many pharmacological effects, as well that antioxidant effect of phenolic compounds has been proven in various experimental systems, aim of this research was to determine the content of total phenols and flavonoids and evaluation of antioxidant activity in ethanol, ethyl acetate and chloroform extracts of fruits and leaves of the plant species Crataegus monogya Jacq., which is known as common hawthorn. The content of total phenolic compounds was determined by the spectrophotometric method using Folin-Ciocalteu reagent and the content of flavonoids was determined using aluminum chloride. In vitro evaluation of the antioxidant activity of tested extracts was performed using the DPPH method. The amount of total phenolics was varied in fruits and leaves extracts and ranged from 38.05 \pm 0.18 to $365.11 \pm 0.32 \mathrm{mg}$ GAE/g dw. Ethyl acetate extract of hawthorn leaves showed the highest content of phenolic compounds $(365.11 \pm 0.32 \mathrm{mg} \mathrm{GAE} / \mathrm{g} \mathrm{dw})$. The flavonoid content was different in the fruits and leaves of hawthorn and ranged from $21.11 \pm 0.11$ to $122.98 \pm 0.21$ $\mathrm{mg} \mathrm{RU} / \mathrm{g} \mathrm{dw}$, whereby the highest content of flavonoids was found in ethyl acetate extract of leaves $(122.98 \pm 0.21$ $\mathrm{mg} \mathrm{RU/g} \mathrm{dw).} \mathrm{Antioxidant} \mathrm{activity} \mathrm{of} \mathrm{the} \mathrm{tested} \mathrm{extracts} \mathrm{was} \mathrm{expressed} \mathrm{as} \mathrm{IC}_{50}$ values and ranged from $5.53 \pm 0.08$ to $293.51 \pm 0.28 \mu \mathrm{g} / \mathrm{ml}$. Ethyl acetate extract of hawthorn leaves showed considerable antioxidant potential $\left(\mathrm{IC}_{\mathbf{5 0}}=\right.$ $5.53 \pm 0.08 \mu \mathrm{g} / \mathrm{ml})$. Based on the obtained results, a significant correlation was found between the antioxidant activity and the content of total phenolics and flavonoids compounds in hawthorn fruits and leaves extracts.
\end{abstract}

Keywords: Phenolics, Flavonoids, Crataegus monogyna, Extracts, Antioxidant activity.

\section{INTRODUCTION}

The connection between man and plants dates back thousands of years ago. Throughout history, plants have gained increasing importance as a source of biologically active substances. It is known that the use of medicinal herbs is a significant factor that improves the general health of people, and the study of its positive impact is more and more the subject of current research. This property is explained primarily by the presence of secondary metabolites in plants, which can exhibit different biological activities. Phenolic compounds are widespread products of secondary metabolism and the antioxidant activity of plant extracts is mainly related to their presence (Kaur \& Kapoor, 2008). The most common phenolic compounds are phenolic acids (benzoic and cinnamic acid derivatives), flavonoids, stilbenes, lignans, coumarins and tannins. Due to their pronounced antioxidant activity, phenolic compounds have the ability to directly bind ("catch") free radicals (Kancheva, 2009; Rice-Evans et al., 1996; Kirakosyan et al., 2003).

The genus Crataegus, commonly known as hawthorn, comprises about 200 species (Dönmez, 2004). It is widely distributed in the temperate and subtropical regions of the Northern hemisphere, most in North America and somewhat less

* Corresponding author: vidoslav.dekic@pr.ac.rs CHEMISTRY in Europe and Asia. This genus is characterized by deciduous, usually thorny shrubs or low trees about 5-15m high. The lifespan of hawthorn can be over 200 years. Today more than 20 species of hawthorn are used in folk medicine and some of them are found in the pharmacopeias of many countries (Chang et al., 2002). Leaves, flowers, and fruits are used as an herbal drug. The flowers are collected early in the spring when are completely developed, leaves are collected during the summer, and the fruits when are ripe, mid in the fall. Hawthorn flower and leaf contain, as active principles, complexes of flavonoid heterosides in the amount of $1-2 \%$. The fruits contain less flavonoids (about $0.1 \%$ ) but there are more sugars, organic acids, carotenoids, and vitamin C. Hawthorn is considered one of the most valuable and effective cardio protector plants for the heart. It has been observed that extracts of fruits, leaves, and flowers of hawthorn have a beneficial effect on coronary artery flow, contraction of the heart muscle and following this they are used as powerful cardiotonic, hypotensive and antiaritmic agents (Alirezalu et al., 2018; Long et al., 2006; Degenring et al., 2003). In some nations, certain species of the genus Crataegus are used in the treatment of digestive problems, dyspnea and kidney stones (Rigelsky \& Sweet, 2002). Hawthorn extracts also show a wide range of antioxidant, antimicrobial, antifungal, anti-inflammatory and antiviral activities (García-Mateos et al., 2013; Orhan et al., 2007; Tadić et al., 2008; Benli et al., 2008).

Crataegus monogyna Jacq. (common hawthorn) is a deciduous shrub or low tree up to $10 \mathrm{~m}$ high. This species is most 
abundant in the zone of a deciduous forest at 900-1200 m above sea level. In many nations of the world, common hawthorn has a very wide and varied use. Thus, hawthorn fruits are used in culinary, mostly for making jams and drinks (Chang et al., 2002). Fruits and leaves of hawthorn have a mild diuretic, antispasmodic and cardiotonic effect (Barros et al., 2011; Edwards et al., 2012; Nabavi et al., 2015; Fakir et al., 2009). Hawthorn extracts have proved to be beneficial to the nervous system and are used against migraines, memory loss and calming, thus on that way improving overall condition of the organism (Elango \& Devaraj, 2010; Zhang et al., 2004; Novais et al., 2004). Due to the presence of different types of bioactive components, the extracts of leaves, flowers, and fruits of this plant species exhibit extraordinary antioxidant activity (Keser et al., 2014; Konyalioglu et al., 2017; Özcan et al., 2005).

In light of our previous work (Radulović et al., 2020; Živić et al., 2019; Dekić et al., 2019) which is regarding to the pharmacological and antioxidant effects of many plant species from area of Serbia, the aim of this study was to determine the content of phenols and flavonoids and evaluate the antioxidant activity of fruits and leaves extracts of plant species Crataegus monogyna Jacq.

\section{EXPERIMENTAL}

\section{Materials and methods}

\section{Chemicals and reagents}

The solvents (HPLC grade) used in the experimental work were purchased from J.T. Baker (USA) and Merk (Germany) while gallic acid, rutin, and ascorbic acid were purchased from Acros Organics (Belgium). Also, 2,2-diphenyl-1-picrylhydrazyl (DPPH), potassium acetate $\left(\mathrm{CH}_{3} \mathrm{COOK}\right)$ and Folin-Ciocalteu reagent were purchased from Sigma-Aldrich (USA). All other chemicals used in this research were from Merck (Germany) and Fisher Scientific (USA).

\section{$U V$-Vis spectroscopy.}

All absorbance was measured using a LLG UniSPEC 2 spectrophotometer

\section{Plant material}

The fruits and leaves of the plant species Crataegus monogyna Jacq. were collected from the area of Šara mountain at $1150 \mathrm{~m}$ above sea level, in september 2018. After 12 days of drying in the shade, the plant material was packed in dark glass bottles and stored in a dry and dark place until analyzed.

\section{Extraction}

About $8 \mathrm{~g}$ of dried and well grind fruits and leaves of hawthorn were extracted in a Soxhlet apparatus, whereby used $100 \mathrm{ml}$ of solvents with different polarity: ethanol, ethyl acetate and chloroform. The extraction was performed for 6 hours at the boiling point of the solvent. After the expiration of the estimated period time, the extracts were evaporated to dryness on a rotary vacuum evaporator at a temperature of $35{ }^{\circ} \mathrm{C}$. The dry extracts were then packed in vials and kept in the refrigerator at $5{ }^{\circ} \mathrm{C}$ until use.

\section{Determination of total phenolic content}

The total phenolic content of the tested hawthorn fruits and leaf extracts was determined spectrophotometrically with FolinCiocalteu reagent according to the previously described method (Singleton et al., 1999), with slight modifications. The dry extracts were dissolved in methanol $(1000 \mu \mathrm{g} / \mathrm{ml})$ and used during the analysis. Briefly, $1.5 \mathrm{ml}$ of Folin-Ciocalteu reagent (diluted 10 times with distilled water) was added to a test tube with $0.5 \mathrm{ml}$ of extracts and then was shaking. After 2 minutes, 2 $\mathrm{ml}$ of $7.5 \% \mathrm{Na}_{2} \mathrm{CO}_{3}$ solution was added, test tubes were slightly shaken and then incubated at $32{ }^{\circ} \mathrm{C}$ for 90 minutes in a dark place. The same procedure was repeated for gallic acid, which was used to construct the calibration curve, and it was constructed based on different concentrations of gallic acid solution $(1.95-250 \mu \mathrm{g} / \mathrm{ml})$. The absorbance was measured at 765 $\mathrm{nm}$ relative to the blank $(1.5 \mathrm{ml}$ of Folin-Ciocalteu reagent and 2 $\mathrm{ml}$ of $7.5 \% \mathrm{Na}_{2} \mathrm{CO}_{3}$ was added in $0.5 \mathrm{ml}$ of methanol) on LLG UniSPEC 2 spectrophotometer. The total phenolic content of the samples was calculated from the calibration curve equation and results were presented as $\mathrm{mg}$ of gallic acid equivalents per $\mathrm{g}$ of dried weight extracts (mg GAE/g dw).

\section{Determination of total flavonoid content}

The total flavonoid content of extracts was determined spectrophotometrically, using a method based on the formation of complexes between the flavonoids and aluminum (Chang et al., 2002). In $0.5 \mathrm{ml}$ of extracts $(1000 \mu \mathrm{g} / \mathrm{ml})$ was gradually added $1 \mathrm{ml}$ of methanol, $80 \mu \mathrm{l}$ of $10 \% \mathrm{AlCl}_{3}$ solution, $80 \mu \mathrm{l}$ of 1 $\mathrm{M} \mathrm{CH}_{3} \mathrm{COOK}$ solution and $2.5 \mathrm{~mL}$ of distilled water. The same procedure was repeated for the standard solution of rutin (3.91$125 \mu \mathrm{g} / \mathrm{ml}$ ). After incubation at room temperature for 50 minutes, the absorbance was measured at $415 \mathrm{~nm}$ on a spectrophotometer. The blank contained all reagents, except tested extracts, which were replaced with $0.5 \mathrm{ml}$ of methanol. The total flavonoid content was calculated from the calibration curve equation and is expressed as $\mathrm{mg}$ of rutin equivalents per $\mathrm{g}$ of dried weight extract (mg RU/g dw).

\section{DPPH assay}

For the determination of the antioxidant activity of tested extracts the DPPH (2,2-diphenyl-1-picrylhydrazyl) test was used, according to the previously described method (Braca et al., 2001) with small modifications. The procedure was as follows: $0.8 \mathrm{ml}$ of methanolic solution of extracts (3.91-1000 $\mu \mathrm{g} / \mathrm{ml})$ was placed in a test tube and mixed with $2 \mathrm{ml}$ of $0.004 \%$ DPPH methanolic solution. The test tubes were allowed to stand for 45 minutes in a dark place and at room temperature. The blank contained $0.8 \mathrm{ml}$ 
of methanol instead of extracts. The same procedure was repeated for the standard solution of ascorbic acid (1.96-125 $\mu \mathrm{g} / \mathrm{ml}$ ), which in our case was used as a measure of comparison of efficacy with the tested extracts (positive control). The absorbance was measured at $517 \mathrm{~nm}$ on a spectrophotometer. The inhibition of DPPH radicals in the presence of tested samples is calculated by the formula and expressed as a percentage of inhibition $(\%)$ : inhibition $(\%)=((\mathrm{Ab}-\mathrm{As}) / \mathrm{Ab}) \cdot 100$, Ab-absorbance of blank (2 $\mathrm{ml}$ of DPPH and $0.8 \mathrm{ml}$ of methanol), As-absorbance of the methanolic extracts solution $(2 \mathrm{ml}$ of DPPH and $0.8 \mathrm{ml}$ of extracts solution). The results are expressed as $\mathrm{IC}_{50}$ values in $\mu \mathrm{g} / \mathrm{mL}$ ( $\mathrm{IC}_{50}$ value represents the concentration of tested extracts and/or standard antioxidant which inhibited $50 \%$ of the initial concentration of DPPH molecules).

\section{Statistical analysis}

Statistical and numerical analyzes were performed using GraphPad Prism ver. 7.00 and MS Office Excel (2016) software package. All results are presented as the mean of three repetitions ( $\mathrm{n}=3 \pm$ standard deviation).

\section{RESULTS AND DISCUSSION}

Yields (\%), total phenolics and total flavonoids content

Based on the obtained results (Table 1) the yields of isolated hawthorn fruits extracts ranged from 2.03 to $24.51 \%$, while for leaves extracts ranged from 5.15 to $40.69 \%$ (results are expressed in percentages and refer to $100 \mathrm{~g}$ of dry plant material)

Ethanol (ethanolic hawthorn leaf extract) was given the highest yield during the extraction of plant material as the most polar solvent $(40.69 \%)$, while the yield of a chloroform extract (chloroform hawthorn fruit extract) was the lowest (2.03\%).

Table 1. Percentage yields (\%) of Crataegus monogyna Jacq. fruits and leaves extracts.

\begin{tabular}{|l|c|c|}
\hline \multirow{2}{*}{ Extract } & \multicolumn{2}{|c|}{ Percentage yield \% (w/w) } \\
\cline { 2 - 3 } & Fruits & Leaves \\
\hline Ethanol & 24.51 & 40.69 \\
Ethyl acetate & 4.32 & 9.02 \\
Chloroform & 2.03 & 5.15 \\
\hline
\end{tabular}

The concentration of total phenolics compounds in the tested extracts was determined spectrophotometrically (the method is based on the measurement of the reducing capacity of phenolics compounds) and the values were calculated based on the equation obtained from the calibration curve. The total phenolics content of hawthorn fruits and leaves extracts ranged from $38.05 \pm 0.18$ to $152.87 \pm 0.11 \mathrm{mg} \mathrm{GAE} / \mathrm{g} \mathrm{dw}$ for fruits and from $83.36 \pm 0.21$ to $365.11 \pm 0.32 \mathrm{mg} \mathrm{GAE} / \mathrm{g} \mathrm{dw}$ for leaves extracts (Table 2). Based on the obtained results it can be concluded that the total content of phenolics compounds is higher for hawthorn leaves extracts than for fruits extracts. Ethyl acetate extract of leaves showed the highest concentration of phenolics compounds with a value of $365.11 \pm 0.32 \mathrm{mg} \mathrm{GAE} / \mathrm{g}$ $\mathrm{dw}$, while the lowest concentration of phenolics showed chloroform extract of fruits $(38.05 \pm 0.18 \mathrm{mg} \mathrm{GAE} / \mathrm{g} \mathrm{dw})$. In the ethanol extracts of fruits and leaves the content of phenolics compounds was $101.01 \pm 0.12 \mathrm{mg} \mathrm{GAE} / \mathrm{g} \mathrm{dw}$ and $188.21 \pm 0.18$ $\mathrm{mg}$ GAE/g dw, respectively.

Table 2. Content of total phenolics and flavonoids compounds of Crataegus monogyna Jacq. fruits and leaves extracts.

\begin{tabular}{|l|c|c|c|c|}
\hline \multirow{2}{*}{ Extract } & \multicolumn{2}{|c}{$\begin{array}{c}\text { Total phenolics } \\
(\mathrm{mg} \mathrm{GAE} / \mathrm{g} \mathrm{dw})\end{array}$} & \multicolumn{2}{c|}{$\begin{array}{c}\text { Total flavonoids } \\
(\mathrm{mg} \text { RU/g dw })\end{array}$} \\
\cline { 2 - 5 } & Fruits & Leaves & Fruits & Leaves \\
\hline Ethanol & $101.01 \pm 0.12$ & $188.21 \pm 0.18$ & $48.27 \pm 0.26$ & $89.78 \pm 0.13$ \\
Ethyl acetate & $152.87 \pm 0.11$ & $365.11 \pm 0.32$ & $58.81 \pm 0.12$ & $122.98 \pm 0.21$ \\
Chloroform & $38.05 \pm 0.18$ & $83.36 \pm 0.21$ & $21.11 \pm 0.11$ & $36.01 \pm 0.16$ \\
\hline
\end{tabular}

According to numerous studies, the total phenolics content of many plant species depends on the type of extraction as well as the polarity of the used solvents (Mohsen \& Ammar, 2008; Zhou \&Yu, 2004). The content of phenolics compounds, in our case, was highest in ethyl acetate extracts of fruits and leaves and the lowest in chloroform extracts. Base on that the content of phenolics compounds decreases in the order: ethyl acetate > ethanol > chloroform extracts. External factors such as light, temperature, and presence of nutrients in the soil have a significant impact on the composition and amount of phenolics compounds.

Determination of total flavonoids content is based on the property of flavonoids to give a complex with metal ions (such as $\mathrm{Al}^{3+}$ ) whereby chelates are formed and occur a displacement of absorption bands by about $50 \mathrm{~nm}$ toward higher wavelengths bathochromic displacement (Silva et al., 2015). The concentration of total flavonoids in the tested hawthorn fruits extracts ranged from $21.11 \pm 0.11$ to $58.81 \pm 0.12 \mathrm{mg} \mathrm{RU} / \mathrm{g} \mathrm{dw}$ and in leaves extracts from $36.01 \pm 0.16$ to $122.98 \pm 0.21 \mathrm{mg}$ RU/g dw (Table 2). Hawthorn a leaf extracts contains higher amounts of flavonoids than fruit extracts. The highest concentration of flavonoids was in ethyl acetate hawthorn leaves and fruits extracts $(122.98 \pm 0.21$ and $58.81 \pm 0.12 \mathrm{mg} \mathrm{RU} / \mathrm{g} \mathrm{dw}$, respectively), while chloroform leaves and fruits extracts showed 
lowest amount of flavonoids $(36.01 \pm 0.16$ and $21.11 \pm 0.11 \mathrm{mg}$ $\mathrm{RU} / \mathrm{g} \mathrm{dw}$, respectively) Based on the obtained results the flavonoids content decreases in the order: ethyl acetate > ethanol $>$ chloroform extracts. All tested hawthorn fruit and leaf extracts contain a significantly lower amount of flavonoids than the phenolics compounds.

\section{DPPH assay}

The antioxidant activity of the extracts obtained from hawthorn fruits and leaves was determined by the DPPH assay, and the results of the analyzes were expressed as $\mathrm{IC}_{50}$ values in $\mu \mathrm{g} / \mathrm{mL}$, (Figure 1). The lower $\mathrm{IC}_{50}$ values correspond to the stronger antioxidant activity of the extracts.

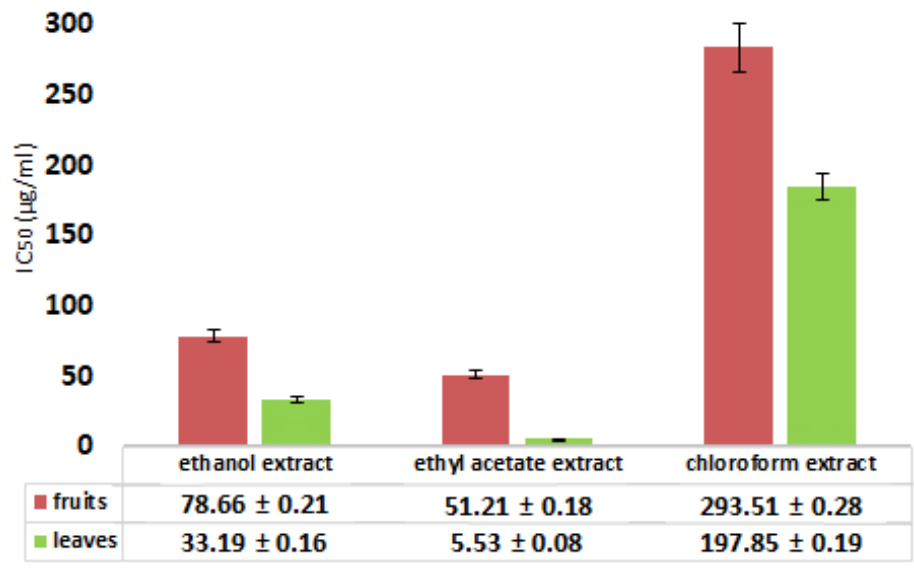

Figure 1. Free radical scavenging activity of Crataegus monogyna Jacq. fruit and leaf extracts expressed as $\mathrm{IC}_{50}$ values $(\mu \mathrm{g} / \mathrm{ml})$ measured by DPPH method. Ascorbic acid was used as positive control $\left(\mathrm{IC}_{50}=3.12 \pm 0.14 \mu \mathrm{g} / \mathrm{ml}\right)$.

All tested extracts showed strong and significant antioxidant activity. Hawthorn leaves extracts showed stronger antioxidant activity compared to hawthorn fruit extracts. Ethyl acetate extracts of fruits and leaves which neutralize $50 \%$ of DPPH radicals at concentrations of $51.21 \pm 0.18 \mu \mathrm{g} / \mathrm{ml}$ and 5.53 $\pm 0.08 \mu \mathrm{g} / \mathrm{ml}$, respectively, showed the highest antioxidant activity. Also, ethanol extracts $\left(\mathrm{IC}_{50}=78.66 \pm 0.21 \mu \mathrm{g} / \mathrm{ml}\right.$ for fruits and $\mathrm{IC}_{50}=33.19 \pm 0.16 \mu \mathrm{g} / \mathrm{ml}$ for leaves extracts) showed a significant and stronger inhibition of DPPH radicals compared to chloroform extracts, which showed lower antioxidant activity $\left(\mathrm{IC}_{50}=293.51 \pm 0.28 \mu \mathrm{g} / \mathrm{ml}\right.$ for fruits and $\mathrm{IC}_{50}=197.85 \pm 0.19$ $\mu \mathrm{g} / \mathrm{ml}$ for leaves extracts). The strong antioxidant activity of all tested extracts is associated with the high content of phenolics and flavonoids compounds and indicates that these compounds contribute to the antioxidant activity of hawthorn fruits and leaves extracts.

\section{Correlation analysis}

The correlation between the antioxidant activity of the hawthorn fruits and leaves extracts and the content of total phenolics and total flavonoids compounds is showed on Figures
2 and 3. Based on the obtained results, a significant degree of correlation between total phenolics content and antioxidant activity $(r=-0.934$ for fruit extracts and $r=-0.859$ for leaves extracts) indicates that the antioxidant properties of the tested extracts originate from the presence of phenolics compounds in the extracts, especially in the case of hawthorn fruits.

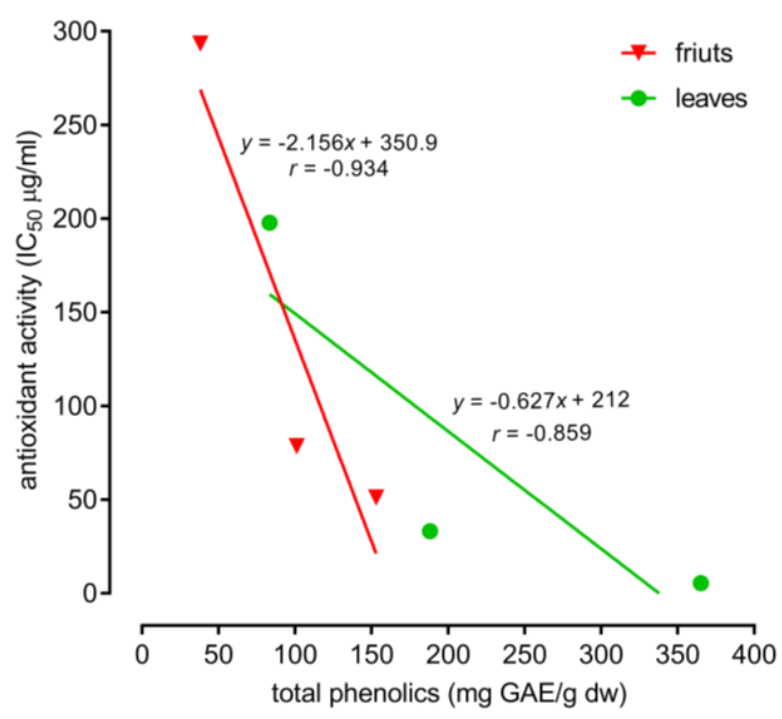

Figure 2. Linear correlation of total phenolics compounds and antioxidant activity of hawthorn fruits and leaves extracts.

An even better and more significant correlation was found between the antioxidant activities of hawthorn fruits and leaves extracts and total flavonoids content. A high degree of correlation in fruit extracts $(r=-0.968)$ and leaves $(r=-0.987)$ indicates that the presence of flavonoids compounds is crucial for the pronounced antioxidant activity of the tested extracts.

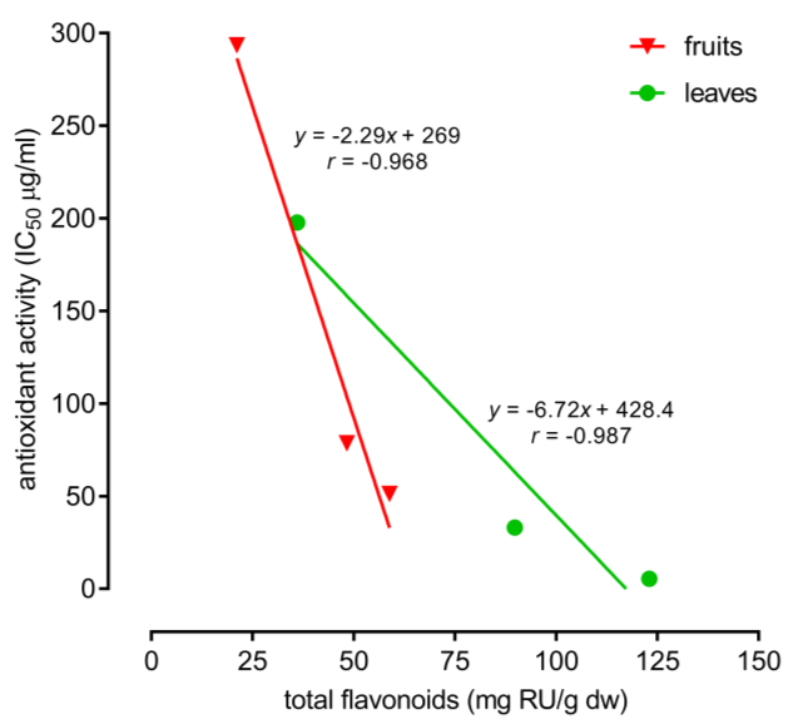

Figure 3. Linear correlation of total flavonoids compounds and antioxidant activity of hawthorn fruits and leaves extracts.

Since a lower $\mathrm{IC}_{50}$ value indicates a higher antioxidant activity, it can be concluded that as the content of phenolics and 
flavonoids increases, the $\mathrm{IC}_{50}$ value decreases. Therefore, the linear correlation is negative and strong, and in our case is particularly pronounced between antioxidant activity and total flavonoids content in all tested extracts.

\section{CONCLUSION}

Hawthorn, as a plant species that has been long used in traditional medicine as well for medical purposes, also widely used in the process of preparing food and many drinks. The presented research showed that hawthorn extracts (Crataegus monogyna Jacq.) have a high content of phenolics and flavonoids compounds, which is directly reflected in their remarkable antioxidant potential. This is confirmed by a significant correlation between the total content of phenolics and flavonoids compounds and antioxidant activity. The results obtained in this study will influence on ethnopharmacological use of fruits and leaves of the plant species Crataegus monogyna Jacq., as well as their potential use in some branches of the pharmaceutical and food industry. This research further shows and classifies hawthorn as a natural source of antioxidants and enhances the picture about the use of hawthorn in traditional medicine for the treatment of many diseases.

\section{ACKNOWLEDGMENTS}

This research was financially supported by the Ministry of Education, Science and Technological Development of Serbia [Project No. 172061 and 45022].

\section{REFERENCES}

Alirezalu, A., Salehi, P., Ahmadi, N., Sonboli, A., Aceto, S., Maleki, H. H., \& Ayyari, M. 2018. Flavonoids profile and antioxidant activity in flowers and leaves of hawthorn species (Crataegus spp.) from different regions of Iran. International Journal of Food Properties, 21(1), pp. 452-470. doi: 10.1080/10942912.2018.1446146

Barros, L., Carvalho, A. M., \& Ferreira, I. C. 2011. Comparing the composition and bioactivity of Crataegus monogyn flowers and fruits used in folk medicine. Phytochemical Analysis, 22(2), pp.181-188. doi: 10.1002/pca.1267

Benli M., Yiğit, N., Geven, F., Güney, K., \& Bingöl, Ü. 2008. Antimicrobial activity of endemic Crataegus tanacetifolia (Lam.) Pers and observation of the inhibition effect on bacterial cells. Cell Biochemistry and Function, 26(8), pp. 844-851. doi: 10.1002/cbf.1515

Braca, A., Tommasi, N. D., Bari, L. D., Pizza, C., Politi, M., \& Morelli, I. 2001. Antioxidant Principles from Bauhinia terapotensis. Journal of Natural Products, 64(7), pp. 892-895. doi: $10.1021 / \mathrm{np0100845}$

Chang, C., Yang, M., Wen, H., \& Chern, J. 2002. Estimation of Total Flavonoid Content in Propolis by Two Complementary Colorimetric Methods. Journal of Food and Drug Analysis, 10(3), pp. 178-182.
Chang, Q., Zuo, Z., Harrison, F., \& Chow, M. S. 2002. Hawthorn. The Journal of Clinical Pharmacology, 42(6), pp. 605-612. doi: 10.1177/00970002042006003

Degenring, F. H., Suter, A., Weber, M., \& Saller, R. 2003. A randomised double blind placebo controlled clinical trial of a standardised extract of fresh Crataegus berries

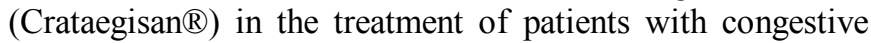
heart failure NYHA II. Phytomedicine, 10(5), pp. 363-369. doi: 10.1078/0944-7113-00312

Dekić, B. R., Ristić, M. N., Mladenović, M. Z., Dekić, V. S., Ristić, N. R., Ranđelović, V., \& Radulović, N. S. 2019. Diethyl-Ether Flower Washings of Dianthus cruentus Griseb. (Caryophyllaceae): Derivatization Reactions Leading to the Identification of New Wax Constituents. Chemistry \& Biodiversity, 16(7): e1900153. doi: 10.1002/cbdv.201900153

Dönmez, A. 2004. The Genus Crataegus L. (Rosaceae) with Special Reference to Hybridisation and Biodiversity in Turkey. Turkish Journal of Botany, 28(1), pp. 29-37.

Edwards, J. E., Brown, P. N., Talent, N., Dickinson, T. A., \& Shipley, P. R. 2012. A review of the chemistry of the genus Crataegus. Phytochemistry, 79, pp. 5-26. doi: 10.1016/j.phytochem.2012.04.006

Elango, C., \& Devaraj, S. N. 2010. Immunomodulatory effect of Hawthorn extract in an experimental stroke model. Journal of Neuroinflammation, 7(1): 97. doi: 10.1186/1742-2094-7-97

Fakir, H., Korkmaz, M., \& Güller, B. 2009. Medicinal plant diversity of western Mediterrenean region in Turkey. Journal of Applied Biological. Science, 3(2), pp. 30-40.

García-Mateos, R., Ibarra-Estrada, E., \& Nieto-Ángel, R. 2013. Antioxidant compounds in hawthorn fruits (Crataegus spp.) of Mexico. Revista Mexicana de Biodiversidad, 84(4), pp. 1298-1304. doi: 10.7550/rmb.35675

Kancheva, V. D. 2009. Phenolic antioxidants - radicalscavenging and chain-breaking activity: A comparative study. European Journal of Lipid Science and Technology, 111, pp. 1072- 1089. doi: 10.1002/ejlt.200900005

Kaur, C., \& Kapoor, H. C. 2008. Antioxidants in fruits and vegetables-the millennium's health. International Journal of Food Science \& Technology, 36(7), pp. 703-725. doi: 10.1111/j.1365-2621.2001.00513.x

Keser, S., Celik, S., Turkoglu, S., Yilmaz, Ö., \& Turkoglu, I. 2014. The investigation of some bioactive compounds and antioxidant properties of hawthorn (Crataegus monogyna subsp. monogyna Jacq). Journal of Intercultural Ethnopharmacology, 3(2), pp. 51-55. doi: $10.5455 /$ jice. 20140120103320

Kirakosyan, A., Seymour, E., Kaufman, P. B., Warber, S., Bolling, S., \& Chang, S. C. 2003. Antioxidant Capacity of Polyphenolic Extracts from Leaves of Crataegus laevigata and Crataegus monogyna (Hawthorn) Subjected to Drought and Cold Stress. Journal of Agricultural and Food Chemistry, 51, pp. 3973-3976. doi: 10.1021/jf030096r

Konyalioglu, S., Cebe, E. G., \& Aktar, S. 2017. P 113 Antioxidant activity of Crataegus Monogyna L flowers. Free Radical Biology and Medicine, 108(1), S56. doi: 10.1016/j.freeradbiomed.2017.04.198.

Long, S. R., Carey, R. A., Crofoot, K. M., Proteau, P. J., \& Filtz, T. M. 2006. Effect of hawthorn (Crataegus oxycantha) crude extract and chromatographic fractions on multiple activities 
in a cultured cardiomyocyte assay. Phytomedicine, 13(9-10), pp. 643-650. doi: 10.1016/j.phymed.2006.01.005

Mohsen, S. M., \& Ammar, A. S. M. 2008. Total phenolic contents and antioxidant activity of corn tassel extracts. Food Chemistry, 112(3), pp. 595-598. doi: 10.1016/j.foodchem.2008.06.014

Nabavi, S. F., Habtemariam, S., Ahmed, T., Sureda, A., Daglia, M., Sobarzo-Sánchez, E., \& Nabavi, S. M. 2015. Polyphenolic Composition of Crataegus monogyna Jacq.: From Chemistry to Medical Applications. Nutrients, 7(9), pp. 7708-7728. doi: 10.3390/nu7095361.

Novais M. H., Santos, I., Mendes, S., \& Pinto-Gomes, C. 2004. Studies on pharmaceutical ethnobotany in Arrabida Natural Park (Portugal). Journal of Ethnopharmacology, 93(2-3), pp.183-195. doi: 10.1016/j.jep.2004.02.015

Orhan, I., Özçelik, B., Kartal, M., Özdeveci, B., \& Duman, H. 2007. HPLC Quantification of Vitexine-2"-O-rhamnoside and Hyperoside in Three Crataegus Species and Their Antimicrobial and Antiviral Activities. Chromatographia, 66, pp. 153-157. doi: 10.1365/s10337-007-0283-x

Özcan, M., Hacıseferoğulları, H., Marakoglu, T., \& Arslan, D. 2005. Hawthorn (Crataegus spp.) fruit: some physical and chemical properties. Journal of Food Engineering, 69 (4), pp. 409-413. doi: 10.1016/j.jfoodeng.2004.08.032

Radulović, N. S., Mladenović, M. Z., Ristić, M. N., Dekić, V. S., Dekić, B. R., \& Ristić, N. R. 2020. A new longipinane ketone from Achillea abrotanoides (Vis.) Vis.: chemical transformation of the essential oil enables the identification of a minor constituent. Phytochemical Analysis, published online. doi: 10.1002/pca.2913

Rice-Evans, C. A., Miller, N. J., \& Paganga, G. 1996. Structureantioxidant activity relationship of flavonoids and phenolic acids. Free Radical Biology and Medicine, 20(7), pp. 933956. doi: 10.1016/0891-5849(95)02227-9

Rigelsky, J. M., \& Sweet, B. V. 2002. Hawthorn: Pharmacology and therapeutic uses. American Journal of Health-System Pharmcy, 59(5), pp. 417-422. doi: 10.1093/ajhp/59.5.417

Singleton, V. L., Orthofer, R., \& Lamuela-Raventos, R. M. 1999. Analysis of total phenols and other oxidation substrates and antioxidants by means of Folin-Ciocalteu reagent. Methods in Enzymology, 299, pp. 152-178. doi: 10.1016/S00766879(99)99017-1

Tadić, V. M., Dobrić, S., Marković, G. M., Đorđević, S. M., Arsić, I. A., Menković, N. R., \& Stević, T. 2008. Antiinflammatory, Gastroprotective, Free-Radical-Scavenging, and Antimicrobial Activities of Hawthorn Berries Ethanol Extract. Journal of Agriculture and Food Chemistry, 56(17), pp. 7700-7709. doi: 10.1021/jf801668c

Zhang, D. L., Zhang, Y. T., Yin, J. J., \& Zhao, B. L. 2004. Oral administration of Crataegus flavonoids protects against ischemia/reperfusion brain damage in gerbils. Journal of Neurochemistry, 90(1), pp. 211-219. doi: 10.1111/j.14714159.2004.02480.x

Zhou, K., \& Yu, L. 2004. Effects of extraction solvent on wheat bran antioxidant activity estimation. LWT - Food Science and Technology, 37(7), pp. 717-721. doi: 10.1016/j.lwt.2004.02.008

Živić, N., Milošević, S., Dekić, V., Dekić, B., Ristić, N., Ristić, M., \& Sretić, Lj. 2019. Phytochemical and antioxidant screening of some extracts of Juniperus communis L. and Juniperus oxycedrus L. Czech Journal of Food Sciences, 37(5), pp. 351-358. doi: 10.17221/28/2019-CJFS 